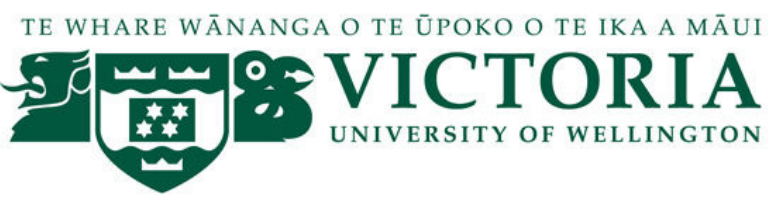

Faculty of Law

Victoria University of Wellington

Security v Privacy

in the Context of Surveillance Measures -

Creating "Glass Citizens"

LLM Research Paper

Counter-Terrorism Law (LAWS 545)

Franziska Liebelt 


\section{Content}

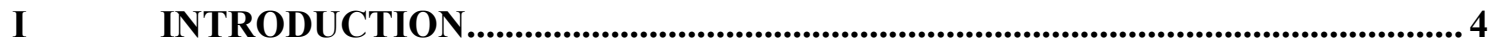

II THE CONFLICT BETWEEN SECURITY AND PRIVACY .............................5

III THE CASE OF EAVESDROPPING IN GERMAN PRIVATE HOMES ............. 6

A History of Counter-Terrorism Law in Germany ........................................................ 6

B Structure of Counter-Terrorism Law in Germany...................................................... 6

C The 1998 Legislative Change to Allow Eavesdropping in Private Homes .............. 7

1 Changes to Article 13 Grundgesetz.................................................................... 8

$2 \quad$ Changes to the Strafprozessordnung ............................................................. 8

D Der Grosse Lauschangriff before the BVerfG.............................................................9

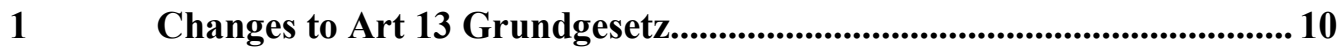

2 Changes to the Strafprozessordnung .................................................. 11

3 The dissenting opinion....................................................................................... 14

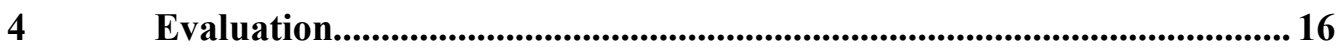

E Legislative Changes Following the Judgment ............................................................ 17

IV THE NEW ZEALAND GCSB AMENDMENT BILL ........................................... 18

A The GSCB Act 2003 .......................................................................................................... 18

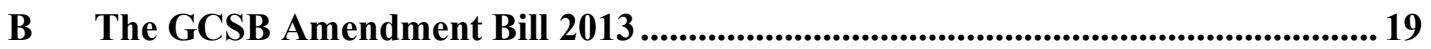

C The Degree of Intrusion into Privacy Rights................................................................... 21

$1 \quad$ Privacy rights in New Zealand ............................................................ 22

2 How intrusive is the new GCSB Act? ........................................................ 24

D Comparison to the German Case Study....................................................................25

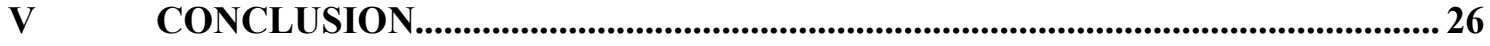

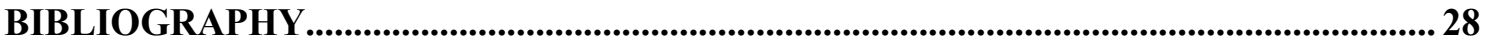


During the last decades states have internationally increased their surveillance measures. Surveillance has become increasingly systematic and integrated in our everyday life. This development was intensified by several terror attacks, specifically the event of 9/11. Surveillance by the state always comes along with the intrusion of privacy rights of individuals. Both privacy and security are essential for a functioning society. To find the right balance between the two interests and to uphold the protection of privacy rights when the threat of terror seems to justify increasingly intrusive measures is difficult but of great importance. This paper looks at two examples of legislations that increased states possibilities for surveillance and how the balance between security and privacy was struck in those legislations. It compares the degree of protection given to privacy rights in a state with a codified constitution, Germany, and in a state with no codified constitution, New Zealand.

The text of this paper (excluding footnotes, table of contents, headings and bibliography) comprises approximately 7800 words.

Abbreviations:

BVerfG - Bundesverfassungsgericht - Federal Constitutional Court

$\mathrm{StGB}$ - Strafgesetzbuch - Criminal Code

StPO - Strafprozessordnung - Code of Criminal Procedure

German provisions are cited as follows:

$\S$ for sections

Roman numbers for subsections 


\section{Introduction}

The conflict between personal rights of liberty and states' interest in security is an issue deeply inherent in counter-terrorism law. ${ }^{1}$ During the last decades governments have globally increased the possibilities for the surveillance of individuals, justified on the grounds that this will enable a better protection from security threats. ${ }^{2}$ This movement wasn't sparked, but definitely inflamed by the $9 / 11$ attacks. The threat by terrorism was suddenly perceived as more eminent than ever before. During the last decades the impression has been shaped that citizens need to give up part of their liberties if they want to be protected from terrorist threats. One of these liberties is the right to move about one's life without being "spied" on by the state. Counter-terrorism laws include provisions that give increasing rights to states to collect data of its citizens through diverse technologies, such as eavesdropping, internet searches or surveillance of phone data. ${ }^{3}$ Passing these laws means taking away more and more liberty rights of the citizens. In Germany this phenomenon has become known as "der gläserne Bürger" which translates to the "glass citizen". This paper analyses the relationship between personal freedom and privacy and security in the context of two national legislations. The first one is a legislative change made in Germany in 1998 increasing the possibilities for eavesdropping for the investigation of particular crimes. This legislative change was challenged before the German Federal Constitutional Court in 2004. The court struck down parts of the legislative package. The second legislation looked at in this paper is the GCSB Amendment Bill recently passed in New Zealand, which changes the GCSB Act 2003. The changes introduced by the Amendment Bill extent the Security Bureau's powers in regards to surveillance measures.

This paper first analyses these two examples of increased surveillance measures. It then assesses how the balance between security and privacy was struck in the two examples and whether any particular differences can be found. The comparison is conducted in light of the fact that Germany has a codified constitution, while New Zealand does not.

1 Verena Zöller "Liberty Dies by Inches: German Counter-Terrorism Measures and Human Rights" (2004) 4 German L J 469, at 471.

2 Kirstie Ball and Frank Webster The Intensification of Surveillance. Crime, Terrorism and Warfare in the Information Age (Pluto Press, London, 2003) at 1 and Jacqueline Klosek The War On Privacy (Praeger, Westport, 2007) at 155.

3 Clive Walker "Keeping Control of Terrorists without Losing Control of Constitutionalism" in David Dyzenhaus (ed) Civil Rights and Security (Ashgate, Surrey, 2009) 331, at 332 and Michael Levi and David S Wall "Technologies, Security, and Privacy in the Post-9/11 European Information Society" (2004) 31(2) Journal of Law and Society 194, at 199 to 205. 


\section{The conflict between security and privacy}

Liberty and security are two aspects that are fundamentally important in democratic societies. ${ }^{4}$ Guaranteeing personal liberties is an intrinsic part of democratic systems and one of these liberties is the right "to be left alone" by the state. ${ }^{5}$ While there is yet no comprehensive definition of the term "privacy", 6 the concept of privacy constitutes "the chore of human dignity, autonomy and freedom." ${ }^{, 7}$ Or, in the words of Tipping $\mathrm{J}:{ }^{8}$

It is the essence of dignity and personal autonomy and well-being of all human beings that some aspects of their lives should be able to remain private if they so wish.

In Germany this is clearly reflected in its constitution. Art 2 I GG reads: "Everyone has the right to free development of his personality insofar as he does not violate the rights of others or offend against the constitutional order or against morality." Due to Germany's historical experience with two regimes that did not provide fundamental civil rights and liberties, German citizens are still particularly sensitive to intrusions by the state. ${ }^{9}$

At the same time it is the state's responsibility to keep its citizens safe. ${ }^{10}$ National security is one of the paramount interests of a society. ${ }^{11}$ There will always be a tension between these two goals in democratic societies. This conflict is particularly strong in counter-terrorism legislation. It is the state's responsibility to find the right balance. ${ }^{12}$

4 Zöller, above n 1, at 471.

5 Samuel D Warren and Louis D Brandeis “The Right to Privacy” (1890) 4 Harv L Rev 193 at 195.

6 Emanuel Gross "The Struggle of a Democracy Against Terrorism - Protection of Human Rights: The Right to Privacy Versus the National Interest - the Proper Balance” (2004) 37 Cornell Int'l L J 27 at 31.

7 Donna-Maree Cross "Surveillance" in Stephen Penk and Rosemary Tobin (eds) Privacy Law in New Zealand (Thomson Reuters, Wellington, 2010) 133 at 135.

8 Hosking $v$ Runting [2005] 1 NZLR 1 at [239] as per Tipping J.

9 Zöller, above n 1, at 472.

10 Jacqueline Klosek The War On Privacy (Praeger, Westport, 2007) at 155 and 156.

11 Thomas I Emerson “Symposium: National Security and Civil Liberties” (1983-4) 69 Cornell L Rev 685 at 685 .

12 Jeremy Waldron "Security and Liberty: The Image of Balance" in Dyzenhaus (ed) Civil Rights and Security (Ashgate, Surrey, 2009) 3, at 4. 


\section{The Case of Eavesdropping in German Private Homes}

\section{A History of Counter-Terrorism Law in Germany}

Although the German counter terrorism law was, like all over the world, revisited after the assault on 9 September 2001, it originates from as early as the 1970s. ${ }^{13}$ At that time, Germany was facing several assaults by the violent left wing movement "Rote Armee Fraktion" 14 which peaked in the so called "German autumn" in 1977. It was then, that the constitutional discourse about the right amount of restriction of freedom in favour of safety occurred for the first time. ${ }^{15}$ Immediately after the 9 September 2001 two legislative packages called the "Safety Packages" or "Anti-Terror-Packages" were adopted, which included both amendments to existing laws and new provisions. ${ }^{16}$ These laws were drafted and adopted quickly and without fundamental research on possible flaws of existing laws and the reality of threats in Germany. ${ }^{17}$ These changes were not so much reactions to the concrete threats of particular terrorists but stemmed from a more general fear of a new type of terrorist activity, a vague phenomenon of an ever-present threat. ${ }^{18}$ The major difference between the terroristic movement of the 1970s and the attack in New York was that the 1970s' terrorists were identified individuals. The terrorists involved in the attack in New York on the other hand were perceived as representatives of a large terroristic network that could strike any time anywhere. ${ }^{19}$ This difference explains why the new legislative actions were seen as necessary, even though terrorism itself had been a long known phenomenon in Germany and Europe. ${ }^{20}$

\section{$B$ Structure of Counter-Terrorism Law in Germany}

The pivotal provision in the German counter-terrorism law is $\S 129$ a Strafgesetzbuch ${ }^{21}$ (StGB), which was enacted in $1976 .{ }^{22}$ This provision punishes the formation of terrorist

13 Oliver Lepsius "Freiheit, Sicherheit und Terror: Die Rechtslage in Deutschland (2004) 32(1) Leviathan 64, at 64.

14 Red Armee Fraction.

15 Lepsius, above $\mathrm{n} 13$, at 64.

16 Gesetz zur Bekämpfung des internationalen Terrorismus (Terrorismusbekämpfungsgesetz), 9 Januar 2002 and Lepsius, above n 13, at 64.

17 Lepsius, above $\mathrm{n}$ 13, at 65 and 66.

18 Lepsius, above n 13, at 66 and Erhard Denninger "Freiheit durch Sicherheit? Anmerkungen zum Terrorismusbekämpfungsgesetz" (2002) (10-11) APuZ 22, at 22.

19 Lepsius, above $\mathrm{n} 13$, at 67.

20 Lepsius, above n 13, at 67.

21 Criminal Code.

22 Gesetz zur Änderung des Strafgesetzbuchs, der Strafprozeßordnung, des Gerichtsverfassungsgesetzes, der Bundesrechtsanwaltsordnung und des Strafvollzugsgesetzes 1976. 
organisations with a prison sentence of 1 to 10 years. It defines a terrorist organisation as an organisation which is founded for the purpose of particular crimes listed in the provision. These crimes include murder, manslaughter, genocide, particular types of abduction, crimes against humanity, war crimes and many more. The provision does not only penalise the act of founding such an organisation but also the mere involvement with one. $\S 129$ b StGB extends the applicability of $\S 129$ a to terrorist organisations abroad. These provisions are cited in many provisions of the Strafprozessordnung ${ }^{23}$ (StPO) to allow certain procedural measures, such as phone tapping.

Apart from these central provisions in the StGB a number of legislative packages making amendments to existing provisions were passed in the 1970s and after the attack of the 11 September 2001. ${ }^{24}$ The central legislative packages were the previously mentioned "security packages" I and II. The first of these concentrated on few restrictive measures, while the second, much more extensive one, focused on preventive measures, and mainly extended the powers of security services and allowed stricter controls of immigrants. ${ }^{25}$ Between 2001 and 2008 a total of 26 legislations and international agreements have been passed in the "fight against terrorism". ${ }^{26}$

\section{The 1998 Legislative Change to Allow Eavesdropping in Private Homes}

Concerning the German legal situation, this paper focuses on some legislative changes that were made in 1998 "for the combat against organised crime". These legislative changes included two different laws: The "Gesetz zur Änderung des Grundgesetzes (Artikel 13)"27 and the "Gesetz zur Verbesserung der Bekämpfung der Organisierten Kriminalität". ${ }^{28}$ The first of these changed art 13 Grundgesetz $^{29}$ (GG) to build the constitutional foundation for eavesdropping in private homes, while the latter added corresponding procedural provisions to the StPO. While these new provisions were not

\footnotetext{
23 Code of Criminal Procedure.

24 Gesetz zur Ergänzung des Ersten Gesetzes zur Reform des Strtafrechts 1974; Gesetz zur Änderung des Strafgesetzbuchs, der Strafprozeßordnung, des Gerichtsverfassungsgesetzes, der Bundesrechtsanwaltsordnung und des Strafvollzugsgesetzes 1976; Gesetz zur Änderung der Strafprozessordnung 1978 and Gesetz zur Bekämpfung des internationalen Terrorismus (Terrorismusbekämpfungsgesetz) 2002.

25 Lepsius, above n 13 , at 68 to 70.

26 http://www.bmj.de/DE/Buerger/buergerMenschrechte/AntiTerrorGesetze/_node.html.

27 Gesetz zur Änderung des Grundgesetzes (Artikel 13) 1998 (Legislation for the Amendment of the Constitution).

28 Gesetz zur Verbesserung der Bekämpfung der Organisierten Kriminalität 1998 (Legislation for Improvement of the Combat against Organised Crimes).

29 Constitution.
} 
officially aimed at terrorist organisations, they constitute part of the general movement towards increasingly intrusive laws that interfere with personal rights of liberty and privacy. ${ }^{30}$ This legislative change became widely known as the "großer Lauschangriff". ${ }^{31}$

\section{Changes to Article 13 Grundgesetz}

Article 13 GG declares the inviolability of the private home and constitutes a specification of the general right of personality protected by art 2 I GG in connection with art $1 \mathrm{I}$ GG, which again is closely connected to the right to human dignity. The right of inviolability of the private home constitutes a so called defensive right of the individual against intrusions into the home by acts of the state. ${ }^{32}$ It protects the right to be "left alone" in the spatial area of one's home. ${ }^{33}$

Before the 1998 amendments, the article had 3 paragraphs. These declared the inviolability of the private home and only allowed searches by order of a judge and by order of other authorities in cases of imminent danger. The amendments to art $13 \mathrm{GG}$ added four paragraphs to the Article that allow eavesdropping in private homes. The main paragraph is the new paragraph 3 which stipulates that:

If particular facts establish the suspicion that someone has committed a particularly serious crime listed in a national law, technical devices of acoustic surveillance may be used for the persecution of the crime in apartments in which the accused presumably sojourns, if the investigation into the situation would otherwise be disproportionately aggravated or become vain. The measure must be terminable. The order is made by a body of three judges. In cases of imminent danger the order can be made by a single judge.

This change introduced a new constitutional exception to the inviolability of the home and allows for the national legislator to specify the new powers of the authorities.

\section{Changes to the Strafprozessordnung}

The amendments to the StPO contained procedural rules around the surveillance under the new art 13 III GG. These rules constitute the "national law" mentioned in art 13 III GG. The central provisions in these changes were $\S 100$ c I No 3, II and III StPO. Under $\S$

30 Zöller, above n 1, at 484 and 485.

31 "Big eavesdrop attack".

32 Theodor Maunz and Günter Düring (founders) Grundgesetz Kommentar (68 ed) (CH Beck, München, 2013) at Art $13 \mathrm{mn} 1$.

33 Verfassungsmäßigkeit handwerksrechtlicher Besichtigungsrechte (1971) (32) BVerfGE 54, 75. 
100c III No 3 "the not publicly spoken word of the accused may be eavesdropped and recorded with technical devices, if particular facts establish the suspicion that the suspect has committed particular crimes" listed in the provision and if the investigation into the situation would otherwise be disproportionately aggravated or become vain. The catalogue of crimes included crimes that are typical for organised criminals, such as money laundering, human trafficking, murder and manslaughter, crimes against the personal freedom, robbery, blackmailing, a number of crimes against the state, leadership of a terrorist organisation and many more. Under $\S 100 \mathrm{c}$ II the eavesdropping is also allowed in homes of other persons than the suspect, if particular facts suggest that the suspect sojourns in these homes, the measures in the home of the suspect are not enough to investigate the case or determine the whereabouts of the suspect and the investigation would otherwise be disproportionately aggravated or become vain.

\section{$D$ Der Grosse Lauschangriff before the BVerfG $G^{34}$}

In 2004 several German citizens filed constitutional complaints against these changes. Significantly, some well-known German politicians were part of the complaint. One of them was the former Minister of Justice, who had resigned when the Government first started to discuss the increase of eavesdropping in private homes in 1996. The complainants disputed the constitutionality of both the amendments to art $13 \mathrm{GG}$ and the amendments to the StPO. ${ }^{35}$ The core of their arguments was that all new provisions constituted an unjustifiable interference with several constitutional rights. ${ }^{36}$ The main invoked constitutional rights were:

- The right to inviolability of the home (art 13 I GG)

- The right to informational self-determination as part of the general personality right (art 2 I in connection with 1 I GG)

- $\quad$ The right to a judicial process (art 19 IV GG)

The Court decided that the amendment of art $13 \mathrm{GG}$ was in line with the requirements for a constitutional amendment but that some of the new procedural arrangements violated the personal rights under art 13 I GG and the general right of personality under art 2 I in connection with art $1 \mathrm{I}$ GG.

34 BVerfG (2004) 1 BvR 2378/98, 1 BvR 1084/99.

35 Above, n 34, at [50] and [57].

36 At [52] to [55] and [57]. 


\section{Changes to Art 13 Grundgesetz}

The BVerfG started with the assessment of the constitutionality of the changes made to art 13 GG. The court first clarified that art 13 I GG does not only protect citizens from physical intrusions in its private home but also from other forms of intrusion, facilitated by modern technologies. ${ }^{37}$ It concluded that the new 13 III GG therefore constituted a restriction on the rights guaranteed under art $13 \mathrm{I} \mathrm{GG}^{38}$ The court then moved on to assess whether the amendment of art $13 \mathrm{GG}$ was consistent with art $79 \mathrm{GG}$, which stipulates the requirements for constitutional changes. ${ }^{39}$ The main requirement under the provision is that a change of the constitution may not "touch" the principles embodied in arts 1 or $20 \mathrm{GG} .{ }^{40}$ These principles are the right to human dignity (art $1 \mathrm{I} \mathrm{GG)}$ ) and the fundamental principles of the Rule of Law and the Social State Principle (art 20 GG). Article 1 III GG furthermore refers to all constitutional rights and therefore prohibits the infringement of all of these rights in so far as such an infringement would collide with the protection of the human dignity guaranteed in art $1 \mathrm{I} \mathrm{GG}^{41}$

The court first defined the elements that constitute human dignity and concluded that the new provisions would infringe this right if it allowed intrusions into the "Kernbereich privater Lebensgestaltung", which translates to the "core sphere of private life". ${ }^{42}$ This area of ultimate human freedom had been shaped by the BVerfG in the Elfes decision in 1957 and constitutes the most private sphere of private life which is entirely protected from intrusions by the state. ${ }^{43}$ The core sphere of private life encompasses the possibility to express highly personal feelings, impressions, thoughts, opinions and experiences without having to fear that the state is eavesdropping on these thoughts. The right to this sphere of intimacy requires the existence of a physical area in which an individual can express these feelings freely. This area is the private home. ${ }^{44}$ The court decided that the amendments to art $13 \mathrm{III}$ did not violate this right for three reasons.

\footnotetext{
37 At [105].

38 At [105].

39 At [108] to [156].

40 Art 79 III GG.

41 Above, n 34, at [109].

42 At [122].

43 Martin Kutscha "Verfassungsrechtlicher Schutz des Kernebreichs privater Lebensgestaltung - nichts neues aus Karlsruhe?” (2005) NJW 20, at 20.

44 Above, n 34, at [120].
} 
Firstly art 13 III GG had to be interpreted in the light of other constitutional provisions. ${ }^{45}$ This would lead to a narrow interpretation which does not cause violations of the core sphere of private life. Secondly art 13 III merely set up the frame for further national legislation which would constitute the true enabling provision. Article 13 III GG only allowed such national legislation that was in accordance with all constitutional law and did therefore not enable unconstitutional infringements by the state. ${ }^{46}$ Thirdly the court saw sufficient requirements for the national law in art 13 III GG, such as the requirement to list certain crimes that would justify eavesdropping, the requirement that the investigations would otherwise be disproportionately difficult or in vain, the requirement of a judicial warrant and the requirement of a time limitation. ${ }^{47}$

\section{Changes to the Strafprozessordnung}

After concluding that the changes to art 13 GG were constitutional the court turned to the new provisions of the StPO. The judgment includes a detailed assessment of the constitutionality of the StPO provisions. The BVerfG has developed a particular pattern for such an assessment. Due to the limited scope of this paper, this section will not follow this pattern but concentrate on the areas that are most relevant in the context.

(a) Scope of protection and infringement

The court first stated the relevant constitutional rights which built the benchmark for the constitutionality of the new provision: ${ }^{48}$

- The inviolability of the home (art 13 I GG)

- The right to informational self-determination as a sub right of the general right of personality (art $2 \mathrm{I}$ in connection with art $1 \mathrm{I}$ )

The BVerfG briefly found that being in your apartment without the surveillance of the state was protected by art 13 I GG and, if you are not in your own but someone else's flat, by art $2 \mathrm{I}$ in connection with art $1 \mathrm{I}^{49}$ The eavesdropping was therefore found to be an infringement of these rights. ${ }^{50}$

\footnotetext{
$45 \quad$ At [124] and [129] to [134].

46 At [114], [124] and [131].

47 At [126] to [128].

48 At [158].

49 At [160]- [162].

50 At [164] - [167].
} 


\section{(b) Justification}

The main part of the Court's assessment was dedicated to the question of justification for these infringements. Here the court assesses whether the provisions conform to pivotal constitutional requirements and whether the provisions are proportionate.

(i) The core sphere of private life

The court started the assessment by determining whether the new provisions of the StPO preserved the core sphere of private life, which, it concluded, was only partly the case. ${ }^{51}$ The provisions violated the core sphere of private life in so far as they did not prohibit the eavesdropping of conversations that were part of this sphere. ${ }^{52}$ This is true for conversations that take place with close family members, other close confidants or persons with professions that involve confidentiality. ${ }^{53} \mathrm{~A}$ violation of this core sphere is always unconstitutional and cannot be justified. The court stated that, in order to be constitutional, the provisions needed to prohibit the eavesdropping and recording of such conversations and provide for the deletion of such conversations if they were accidently recorded. ${ }^{54}$ Furthermore it had to be guaranteed that such recordings could not be used in proceedings. ${ }^{55}$

\section{(ii) Procedural Protection}

The court made two separate comments on the procedural protection provided for by the relevant provisions. The guarantee to procedural protection is embedded in art 19 IV sentence $1 \mathrm{GG} .{ }^{56}$

Firstly, the court found that there was no sufficient procedural protection against the eavesdropping measures ${ }^{57}$ Because the affected persons are notified of the measure only very late or even never, a sufficient procedural protection can only be ensured, if automatic review-mechanisms by authorities other than the prosecution authorities are in place. ${ }^{58}$ The BVerfG said that it was necessary for the provisions to include exact

\footnotetext{
51 At [168].

52 At [171].

53 At [172].

54 At [169] and [179].

55 At [180].

56 Art 19 IV sentence 1 GG: If someone is violated in his rights by the public power, he has a right to judicial process.

57 At [190]- [194].

58 At [191].
} 
regulations on who was in charge of reviewing the admissibility of information gained by eavesdropping and that such a review had to happen ex officio. ${ }^{59}$

Secondly, the court struck down some of the provisions on the notification of affected persons. ${ }^{60}$ The court decided that the StPO provisions violated art 19 IV GG in so far as they included an exception for the notification of the affected persons when the notification was not possible without a threat to the public security or without jeopardizing the further use of a secret agent. ${ }^{61}$ The court found that the general clause "public security" was too wide, because it includes all protected legal rights. The legislative had to specify what legal rights exactly needed to be affected in order to justify not notifying the affected person. ${ }^{62}$

(iii) List of crimes

The BVerfG further examined whether the enumerated crimes in $\S 100 \mathrm{c}$ III No 3 StPO were consistent with art 13 III GG, which allows eavesdropping measures only in cases of "particularly serious crimes". The court said that the catalogue of crimes included in $\S 100$ c III No 3 StPO seemed arbitrary, as the list included crimes with varying severity of penalties, different protected legal interests and different degrees of wrongdoing. ${ }^{63}$ Because eavesdropping constituted a particularly grave intrusion into constitutional rights, this measure needed to be limited by strict requirements, also regarding the seriousness of the crime. ${ }^{64}$ It was not enough to list such crimes that are typical for organised criminals, because these did not necessarily only include serious crimes. ${ }^{65}$ Furthermore not only the abstract listed crime had to be a serious one, but also the particular crime in the particular case. ${ }^{66}$ In the opinion of the BVerfG the penalty of a crime reflects how serious the crime is perceived as by the legislative. ${ }^{67}$ It regards all those crimes as sufficient to justify eavesdropping, which have a maximum penalty of

\footnotetext{
59 At [193].

60 At [288].

61 At [300].

62 At [301].

63 At [226].

64 At [229].

65 At [232].

66 At [234] and [235].

67 At [238].
} 
more than 5 years detention. ${ }^{68}$ By this standard, the list of crimes in $\S 100 \mathrm{c}$ III No 3 StPO was not limited "serious crimes" and was therefore not constitutional. ${ }^{69}$

(iv) Standard of suspicion

Lastly, the court looked at the standard of suspicion required for eavesdropping which was "when particular facts justify the suspicion" that one of the listed crimes has been committed. ${ }^{70}$ The court stated that this level of suspicion required more than just the existence of clues. It required a specific factual basis of a certain scope and only previously investigated facts could be used for this basis. ${ }^{71}$ The court decided that this standard of suspicion was appropriate, because the eavesdropping was a measure of collecting evidence, as opposed to a measure of punishment, such as detention, which would require a stronger standard of suspicion. ${ }^{72}$

\section{The dissenting opinion}

Two of the judges on the bench ${ }^{73}$ in the case filed a joint dissenting opinion that raises some interesting concerns in regards to the majority judgment. The dissenting opinion focuses on the constitutional change. The dissenting judges were of the opinion that the changes made to art $13 \mathrm{GG}$ were unconstitutional because they violated the privacy rights guaranteed by art $1 \mathrm{GG}$.

The judges' argument can be broken down into two steps. Firstly, they established that the plain language of art $13 \mathrm{III} \mathrm{GG}$ constituted a violation of the rights to human dignity and privacy in your home because it did not provide a high enough protection of the core sphere of private life. Secondly, they argued that the level of protection required for these constitutional rights should be included in the language of art $13 \mathrm{GG}$ and that the conflict with arts 1 I and 79 III GG could not be remedied by a restrictive interpretation or narrow executing national provisions.

(a) Violation of constitutional rights

\footnotetext{
68 At [238].

69 At [225]; not serious enough crimes included: money laundering, bribery, corruption, revelation of state secrets, support of a terrorist groups and many more.

$70 \S 100$ c I No 3 StPO.

71 At [247].

72 At [248] and [249].

73 There were 8 judges on the bench in total.
} 
One of the judges' main concerns was that it was impossible for the officials to find out whether the recording violated the core sphere of private life without first listening to the conversation. ${ }^{74}$ The exclusion of conversations that fall into the private sphere always first required a violation of this sphere. ${ }^{75}$ The officials that were in charge of eavesdropping would not be able to "delete" a private conversation from their brains ones they had overheard it. The knowledge so acquired would be able to influence the investigations. In the eyes of the dissenting judges this constituted an unjustifiable violation of the right to privacy in private homes. They furthermore criticised the fact that the provision provided for the eavesdropping of conversations of third persons, particularly in their own flats, which enabled investigations against persons that were previously no suspects. ${ }^{76}$

\section{(b) Certainty of the language of art $13 \mathrm{GG}$}

The judges concluded that art 13 III GG itself did not set high enough limits to protect the rights protected in art $13 \mathrm{I} \mathrm{GG}$ and art $1 \mathrm{GG}$, which as such had been accepted by the majority of the court as well. The dissenting judges did not agree with the majority of the court in that an interpretation of art $13 \mathrm{GG}$ in light of the other constitutional provisions lead to the constitutionality of art $13 \mathrm{III} \mathrm{GG} \mathrm{itself.}{ }^{77}$ In their opinion the conflict with the right to human dignity created by art 13 III GG cannot be sufficiently resolved by a restrictive interpretation of art $13 \mathrm{III} \mathrm{GG.}{ }^{78}$ The dissenting judges alleged that such an approach reduced the right to human dignity to a mere tool of interpretation in order to make constitutional changes constitutional and that this was not living up to the function of the right of human dignity as an absolute limit to intrusions into privacy rights. ${ }^{79}$ The judges furthermore alleged that the interpretation undertaken by the BVerfG amounted to a change of the constitutional provision that fell into the responsibility of the constitutional law maker to maintain the separation of powers. ${ }^{80}$

The constitutionality of the constitutional provision can in their view furthermore not be remedied by stricter provisions in the code of criminal procedure. Instead, the judges found it necessary to include restrictions to protect the core sphere of private life in the

\footnotetext{
74 At [358].

75 At [358].

76 At [363].

77 At [365] to [367].

78 At [369].

79 At [367].

80 At [370].
} 
constitutional provision itself in order to maintain clarity and in order to guarantee a protection of the human dignity on the constitutional level. ${ }^{81}$

The dissenting judges concluded: ${ }^{82}$

\begin{abstract}
Nowadays it seems to be an accepted assumption that with the development of new technological devices the application of these devices is to be accepted. But if the personal intimate sphere in the form of the private home is no longer a taboo zone, a violation of which cannot be justified by security reasons, it is questionable whether the image of humanity drawn by such practises is compatible with the order of a free democratic state of law.
\end{abstract}

\title{
4 Evaluation
}

The BVerfG in this case had the very difficult task to strike a balance between allowing measures to maintain the security of the citizens and protecting the citizens' right to privacy. Because there is no constitutional right to security, the assessment did not so much constitute a weighing up of two constitutional rights but rather required the court to draw boundaries for the right of privacy. This task was particularly difficult in this case because it included the assessment of a constitutional change, which is not an everyday type of task, even for the constitutional court. Regarding the changes to art $13 \mathrm{GG}$ one can assume that the court was reluctant to find that they were unconstitutional, as the change of the constitution is a rare and complicated process.

The criticism of the dissenting judges that even a deleted conversation can influence the investigations ones the police took notice of it is well founded. However, the only remedy for this problem would be to ban eavesdropping entirely. Eavesdropping is a very important investigation measure and often the only hope for the officials to find a lead in the case. To remove this measure from the investigations entirely would inhibit the police work disproportionately, particularly when keeping in mind that there are procedural rules that forbid the use of this information.

The part of the judgment that seems surprising is that the court did not have issues with the authorization of the officials to eavesdrop in third persons' apartments. The intrusion into the private sphere through eavesdropping is a very strong measure, as was identified

81 At [360] and [362].

82 At [373]. 
by the BVerfG itself. It is startling that such an intrusive measure can be justified in regards to the apartment of a person who is under no suspicion.

Regarding the assessment of the StPO provisions it can be noted that the court undertook a very detailed analysis. As a result of this analysis the judges made detailed suggestions on what the provisions need to include to protect the privacy of the affected persons sufficiently. The judges upheld a higher threshold for the justification of eavesdropping measures than the legislative had intended and particularly emphasised the rights to legal protection and the core sphere of private life.

\section{E Legislative Changes Following the Judgment}

After the judgment of the BVerfG, the legislature had to change the StPO in the aspects that had been struck down by the court. This was done through legislation passed in June $2005 .{ }^{83}$ The following changes were made to ensure the constitutionality of the law:

- The list of crimes included in $\S 100 \mathrm{c}$ was limited to crimes that have a maximum penalty of more than 5 years detention.

- A new $\S 100 \mathrm{c}$ IV stipulates that the eavesdropping measures are only allowed if it is guaranteed that no conversations that form part of the core sphere of private life are recorded. However, conversations about crimes already committed or crimes to be committed in the future are "usually not part of this sphere" under the section.

- A new subsection $\mathrm{V}$ was added which requires the officials to interrupt the eavesdropping if conversations that are part of the core sphere of private life are recorded. Under the subsection, such recordings are to be deleted immediately and the knowledge of such recordings cannot be used for the investigations.

- The new $\S 100 \mathrm{~d}$ VIII StPO regulates the notification of the affected persons. The exceptions for the protection of a secret agent and the "public security" were removed.

- Lastly, the new provisions provide for the supervision of the responsible court in several places. ${ }^{84}$

83 Gesetz zur Umsetzung des Urteils des Bundesverfassungsgerichts vom 3. März 2004 (Akustische Wohnraumüberwachung).

${ }^{84} \S 100 \mathrm{c}$ VII, 100d IV, §100d X. 


\section{The New Zealand GCSB Amendment Bill}

The second example of a legislative change that introduces increased intrusions of privacy is a legislative amendment very recently passed in New Zealand. On the 21 August 2013 the New Zealand Parliament passed the Government Communications Security Bureau and Related Legislation Amendment Bill (GCSB Amendment Bill). This bill changed the Government Communications Security Bureau Act 2003 which governs the powers of the Security Bureau. During the legislative process the concern of the public rose regarding the effect of the changes. This concern was caused by the fact that the new bill allowed the Security Bureau to employ their measures on New Zealand citizens, while the measures had previously been limited to foreigners. This section explains the legal changes made to the Act. It looks at the Bill's effect on the privacy rights of New Zealand citizens and draws a comparison to the German case study.

\section{A The GSCB Act 2003}

The GCSB Act 2003 was part of the New Zealand counter terrorism legislation following the $9 / 11$ attacks. ${ }^{85}$ The Act regulates the objectives and functions of the Bureau, which had been established in 1977. ${ }^{86}$ The measures available to the Bureau for intelligence gathering focus on the interception of communications through various technical devices.

The original purpose of the Security Bureau was to provide: ${ }^{87}$

New Zealand government departments with advice on all matters relating to foreign intelligence derived from the interception and exploitation of foreign communications and other signals (such as radar). These include radio, satellite and other forms of telecommunications (including facsimiles and telephones).

The GCSB focused on foreign intelligence and included no powers regarding New Zealand nationals. ${ }^{88}$ This was made clear by section 14 of the Act: ${ }^{89}$

\section{Interception not to target domestic communications}

Neither the Director, nor an employee of the Bureau, nor a person acting on behalf of the Bureau may authorise or take any action for the purpose of intercepting the

\footnotetext{
85 Cynthia Laberge “To What Extent Should National Security Interests Override Privacy in a post 9/1 World?" (2008) 3 Victoria University of Wellington Law Review Working Paper Series at 108.

86 Laberge, above n 85, at 111.

87 Laberge, above $\mathrm{n} 85$, at 111.

88 Laberge, above n 85, at 112.

89 Government Communications Security Bureau Act 2003, s 14.
} 
communications of a person (not being a foreign organisation or a foreign person) who is a New Zealand citizen or a permanent resident.

Under section 15 a warrant was needed for all interceptions that required the physical instalment of an interception device. Section 16 permitted interception of communication without a warrant. The section included several exceptions, one of them regarding private communications, stating that communications may be intercepted only if: ${ }^{90}$

(d) the foreign communications do not contain private communications other than private communications that -

(i) are produced, sent, or received by, or sent to, a foreign organisation or a foreign person; and

(ii) contain, or may reasonably be expected to contain, foreign intelligence.

Section 4 of the GCSB Act defines "private communications" as follows:

\section{private communication-}

(a) Means a communication between 2 or more parties made under circumstances that may reasonably be taken to indicate that any party to the communication desires it to be confined to the parties to the communication; but

(b) Does not include a communication occurring in circumstances in which any party ought reasonably to expect that the communication may be intercepted by some other person not having the express or implied consent of any party to do so

Foreign communications were therefore allowed to be intercepted with the exception of private conversations, unless the private conversations could be reasonably expected to contain foreign intelligence New Zealand citizens on the other hand were entirely protected from interception of their communication. It can therefore be noted that the old system treated foreigners and citizens differently.

\section{$B \quad$ The GCSB Amendment Bill 2013}

In August 2013 the GCSB Amendment Bill was passed. This new legislation caused much public discussion for several reasons. The main reason was probably that the public was not informed sufficiently about the changes that the Amendment Bill brought about. Because the section on the exclusion of New Zealand citizens was amended, the public feared that the Security Bureau would start spying on New Zealand citizens. The

90 Section 16(2)(d). 
parliament chose to pass the Bill in a procedure of Parliamentary Urgency, which caused further resistance of the public. This type of procedure means that there is less time for consultation and submissions, which caused the New Zealand Law Society to be concerned that "its use degrades the democratic quality of the legislative process." 91 The GCSB Amendment Bill transforms the Security Bureau from a foreign intelligence agency to a mixed foreign and domestic intelligence agency. ${ }^{92}$ Furthermore the Amendment allowed the Bureau to pass on the collected data to other government agencies. ${ }^{93}$

The Explanatory Note to the GCSB Amendment Bill names two main reasons for the amendments. Firstly, some interpretative issues had been identified in connection with the GCSB Act 2003. The amendments were to resolve these issues. ${ }^{94}$ The second reason for changing the functions of the Security Bureau named by the explanatory note is that "New Zealand faces a changing security environment in which threats are increasingly interconnected and national borders are less meaningful". 95

The Amendments include numerous changes of the GCSB Act 2003 which cannot all be covered in this section. The relevant changes for the question of intercepting communications are the amendments made to sections $8 \mathrm{~A}$ to $8 \mathrm{C}$ and 14 . Sections $8 \mathrm{~A}$ to $8 \mathrm{C}$ lay out the different functions of the Bureau: information assurance and cybersecurity (8A), intelligence gathering and analysis (8B) and co-operation with other entities to facilitate their functions $(8 \mathrm{C})$.

The changes made to s 14 were the ones that caused the most public concern. This section was changed from prohibiting any interception into communications of New Zealand citizens to only prohibiting the intercepting of private communications of New Zealand citizens. Furthermore this restriction is now limited to the Bureau's function named in section $8 \mathrm{~B}$, whereas under the old section 14 "any action for the purpose of intercepting the communications of a person who is a New Zealand citizen or a permanent resident" was prohibited. Therefore the only activity that remains prohibited in regards to New Zealand Citizens is "Intelligence gathering and analysis" of private communications.

91 New Zealand Law Society Submission on the Government Communications Security Bureau and Related Legislation Amendment Bill (14.6.2013) at [4].

92 New Zealand Law Society, above n 91, at [3].

93 New Zealand Law Society, above n 91, at [9].

94 Government Communications Security Bureau and Related Legislation Amendment Bill Explanatory Note at 2.

95 At 2. 
Section 16 now also explicitly prohibits the interception of private communications of national citizens and permanent residents: ${ }^{96}$

(1A) This section -

(b) does not authorise anything to be done for the purpose of intercepting the private communications of a New Zealand citizen or permanent resident of New Zealand.

On the other hand $\mathrm{s} 16$ subs (2)(d) that prohibited the interception of private communications of foreigners has been removed, which means that the private sphere of foreigners is no longer protected under the GCSB Act.

In summary, the following changes were made that are relevant to individuals' privacy rights:

In regards to New Zealand citizens and permanent residents:

- The Bureau is now authorised to execute all its powers in regards to non-private conversations

- The bureau is not authorised to gather information under section $8 \mathrm{~B}$ by intercepting private conversations

In regards to foreigners:

- The Bureau is now authorised to execute all its powers in regards to both private and non-private communications

\section{The Degree of Intrusion into Privacy Rights}

Unlike in the case of the German legislative change, there has been no case assessing the intrusion of privacy rights through the changes made to the GCSB Act. A full legal analysis of the possible violations of privacy rights by the change is outside the scope of this paper. However, a short summary of the privacy rights existing in New Zealand shall be made in order to be able to put the comparison with the German legislation into perspective. That way a comparison can be made between the level of balance between privacy and security reached by the German legislation on the one hand and by the New Zealand legislation on the other hand. The point of interest is in particular, whether the fact that the right to privacy in Germany is protected in its written constitution makes a

96 Government Communications Security Bureau and Related Legislation Amendment Bill 2013, s $16(1 \mathrm{~A})$. 
difference for the protection of the privacy rights of its citizens compared to a state like New Zealand that does not have a written constitution.

\section{Privacy rights in New Zealand}

There are two main documents regarding privacy rights in New Zealand: The Bill of Rights and the Privacy Act 1993. Furthermore there is a tort against invasion of privacy.

\section{(a) Bill of Rights Act}

The Bill of Rights Act 1990 is part of New Zealand's un-codified constitution. ${ }^{97}$ The Act confirms fundamental human rights for all persons in New Zealand. ${ }^{98}$ The main difference to a codified constitution, such as the German one, is that the Bill of Rights Act does not have a superior position or overriding power in relation to any other national legislation. It has the same status as any other statute of the Parliament. ${ }^{99}$ Therefore, no particular requirements apply for its amendment. ${ }^{100}$ The status of the Act is expressively clarified by s 4 of the Bill of Rights Act. The government must have regard to the Bill of Rights when enacting legislation and legislation has to be interpreted in the light of the rights protected in the Act. ${ }^{101}$ However, if the government passes legislation that is inconsistent with one of the rights, the courts are, due to section 4 of the Bill of Rights Act, not able to rule on the invalidity of the legislation.

The Bill of Rights Act does not include a stand-alone privacy right as such. However, s 21 of the Bill of Rights Act has been interpreted to include "values and interests that comprise the concept of privacy." 102 Section 21 was originally created to protect persons from "unreasonable search and seizure, whether of the person, property, or correspondence or otherwise". ${ }^{103}$ According to s 3 of the Bill of Rights Act, the rights are applicable to relationships between citizens and state agencies. Section 21 therefore protects the citizens from state powers of search. In the watershed case of $R v$ Jefferies, ${ }^{104}$ the court acknowledged that physical intrusions into a person's property did no longer sufficiently capture the intrusions of privacy possible in reality. Thomas $\mathrm{J}$ stated that

97 Paul Rishworth and others The New Zealand Bill of Rights (Oxford University Press, Auckland, 2004) at 3.

98 Rishworth and others, above $\mathrm{n} 97$, at 1.

99 Rishworth and others, above $\mathrm{n} 97$, at 2.

${ }^{100}$ Rishworth and others, above $\mathrm{n} 97$, at 2.

101 Rishworth and others, above n 97, at 3 and 4.

102 Cross, above n 7, at 149 and Rishworth and others, above n 97, at 420.

103 Bill of Rights Act 1990, s 21.

$104 R v$ Jefferies [1994] 1 NZLR 290. 
"[e]ssentially, s 21 is concerned to protect those values or interests which make up the concept of privacy." 105 In this sense, the rights protected under s 21 include "the right of self-determination and control over knowledge about oneself and when, how and to what extent it will be imparted." ${ }^{\prime 106} \mathrm{He}$ also recognised that: ${ }^{107}$

While necessarily phrased in terms of individual values, the community has a direct interest in the recognition and protection of this broad right to privacy. It is a valued right which is esteemed in modern democratic societies.

While all of the statements made in this case indicate a broad protection of privacy rights under s 21 , it has not yet been resolved by the courts in how far exactly s 21 protects from the intrusion of privacy through, for example, surveillance measures. ${ }^{108}$

(b) The Privacy Act 1993

The second pivotal legislation for privacy rights in New Zealand is the Privacy Act of 1993. This Act codifies some foundational principles about the collection, use and dissemination of personal information by private and public agencies. The Act applies to any person in New Zealand. ${ }^{109}$ According to its long title, the Act's purpose is "to promote and protect individual privacy." The guidelines set up by the Act comprise 12 "Information Privacy Principles" which are listed in section 6 of the Act. These guidelines include principles on the collection, storage and the correction of data as well as limits to the use of the date. Examples are the requirement that personal information may only be collected for a lawful purpose and that the individual should be made aware that the information is being collected. ${ }^{110}$

The Act has several weaknesses to it that minimise the protection it actually offers to individuals. Firstly, there are numerous exceptions for the principles. ${ }^{111}$ Secondly, the Privacy Act is limited to the aforementioned principles and does not include any rules. It

\footnotetext{
105 At 319 as per Thomas J.

106 At 319 as per Thomas J.

107 At 319 as per Thomas J.

${ }^{108}$ Cross, above n 7, at 150 and 151 and Stephanie Sue-Ling NG "Leave Me Alone! Should the Right of Privacy Be Included in the New Zealand Bill of Rights Act 1990?" (LLB (Hons) Research Paper, Victoria University of Wellington, 2004) at 17.

109 Stephen Penk “The Privacy Act 1993“ in Stephen Penk and Rosemary Tobin (eds) Privacy Law in New Zealand (Thomson Reuters, Wellington, 2010) 49 at 60.

110 Privacy Act 1993, s 6.

111 Privacy Act 1993, s 6(4).
} 
is very soft legislation with a focus on education and conciliation and does not provide any strict principles that individuals could rely on. Thirdly, according to section 66 of the Privacy Act an interference with an individual's privacy is only established if, additionally to the breach of one of the principles, there was harm caused to the affected individual. Lastly, the principles are not enforceable in Court. Instead, the Act provides for a complaints system in front of a Privacy Commissioner. ${ }^{112}$

\section{(c) Privacy Tort}

Lastly privacy rights are protected by a privacy tort. This was acknowledged in Hosking $v$ Runting, ${ }^{113}$ where the Court of Appeal established that, for a successful claim under this tort, the claimant had to establish that the concerned information could be considered as private and that a publicity was given to this information that would be considered highly offensive to an objective reasonable person. ${ }^{114}$ The concept of the tort for invasion of privacy is still very young and its exact conditions are yet unclear.

\section{How intrusive is the new GCSB Act?}

The main changes affecting privacy rights brought about by the amendments have already been summarised. ${ }^{115}$ Without conducting a comprehensive legal analysis of infringements of the privacy rights provided for in New Zealand, some observations as to the protection of privacy under the provisions can be made.

Section $15 \mathrm{~A}(2)$ lists some requirements that have to be met to allow an interception warrant:

- The interception must fulfil a function of the Bureau.

- The outcome sought to be achieved must justify the particular interception or access.

- The outcome is not likely to be achieved by other means.

- Satisfactory arrangements are in place to ensure that nothing will be done in reliance on the warrant or authorisation beyond what is necessary for the proper performance of a function of the Bureau.

- The nature and consequence of acts done in reliance on the warrant are reasonable.

\footnotetext{
112 Penk, above n 109, at 63 and 78.

${ }^{113}$ Hosking v Runting [2005] 1 NZLR 1.

114 At [117] and Tobin, above $n$ 112, at 85.

115 At IVB.
} 
The Act therefore does require necessity of the measure and reasonableness. However, the extensiveness of the GSCB Act raises some concerns. In regards to the extensive options for spying on foreigners it can be said that an infringement of privacy rights seems possible. If s 21 of the Bill of Rights Act prohibits unreasonable surveillance through technological devices, the unrestricted surveillance measures allowed by the GCSB Act in regards to foreigners seems problematic. This concerns in particular the interception of private communication. In general the different treatment of foreigners and citizens in the GCSB Act is a concern. ${ }^{116}$ It is unclear from the Act how this different treatment can be justified.

In regards to New Zealand citizens and residents it is unclear what measures are allowed by ss $8 \mathrm{~A}$ and $8 \mathrm{C}$ of the GCSB Act and whether these might include the collection of data. Furthermore, while the private communications of New Zealand citizens and residents seem to be comprehensively protected by section 14 , it is unclear how this protection is achieved exactly. For example it is not clarified what happens to private conversations that are recorded accidently. While s 23 of the GCSB Act requires the destruction of "irrelevant records", it includes a wide exception for records that are of use for any purpose of the Bureau. No provision explicitly requests the deletion of private communications. Furthermore, section 15B(a) suggests that there are circumstances under which private conversations of New Zealand citizens or residents may in fact be intercepted. Yet, it is unclear, under which circumstances this can be the case. Another issue with the protection of private conversations is the definition of "private communication" in s 4 of the GCSB Act and its subs (2) which excludes content from being a private communication if "any party ought reasonably to expect that the communication may be intercepted by some other person." ${ }^{117}$ Lastly, the GCSB Act does not include any regulations on informing the affected persons of the intelligence measures, which is one of the principles under the Privacy Act.

\section{$D$ Comparison to the German Case Study}

Even though the GCSB Act and the German Code of Criminal Procedure fulfil different functions, they both represent the movement towards growing measures of surveillance and can be compared as indicators of the attitude towards privacy and security in the two countries. Comparing the balance struck between privacy and security in the New Zealand example on the one hand and the German example on the other hand it can be

116 New Zealand Law Society, above n 91, at [38].

117 New Zealand Law Society, above n 91, at [35]. 
concluded that the protection of privacy rights in New Zealand is considerably weaker than in Germany.

Some immediate examples of the different level of protection in these two legislations are that the GCSB Act does not provide an independent review system, does not protect the private sphere of foreigners and further more allows the exception mentioned above for the protection of the private sphere of New Zealand citizens in the definition of "private communications". The mere fact that one party to the conversation might suspect that the conversation is being eavesdropped does however not change the fact that the conversation might contain highly private content contributed by the persons that do not suspect to be under surveillance. The exception therefore results in possibly highly personal content being unprotected. Furthermore, the GCSB Act does not include regulations on informing the affected persons of the surveillance, on the deletion of private content that was recorded accidently and the surveillance measures do not depend on the suspicion of any particular crime but merely require that they fulfil one of the extensive functions under ss $8 \mathrm{~A}$ and $8 \mathrm{~B} .{ }^{118}$ All of these factors would not comply with the requirements set up by the BVerfG in the case on eavesdropping in private homes.

The difference in the level of protection of privacy rights can be ascribed to the fact that privacy is a constitutionally protected right in Germany, while New Zealand does have constitutional rights as such. The legislative change that was caused in Germany due to the constitutional complaints that were made would not be possible in a comparable way in New Zealand. The fact that New Zealand does not have a constitutional system with a constitutional court leads to a weaker protection of the citizens' rights. Even if the New Zealand courts ascribed s 21 of the Bill of Rights Act the protection of privacy rights in a broad sense, the courts would not be able to declare any legislation violating these rights to be void.

\section{$V$ Conclusion}

The significance of the BVerfG judgment is that it raised boundaries for the surveillance by the state, which some authors thought never possible. ${ }^{119}$ The court emphasised and further specified the boundaries of the core sphere of private life. This core sphere represents the minimum personal liberty absolutely protected by the German constitution which cannot be touched by the state. The court clarified how the inviolability of the private home is closely linked to this sphere. Apart from this "absolute" sphere, the court

118 GCSB Act 2003, ss 15A(1), 15A(2) and 16(1A).

119 Waldron, above n 12 , at 3. 
set further guide lines of minimum procedural protection and proportionality between the measure and the seriousness of the crime. The judgment shows that even in times of "war like emergency", ${ }^{120}$ courts are willing to fulfil their role of judicial control and protect citizens' rights of liberty. Even if the balance between liberty and security might have shifted towards the latter during the last decades, ${ }^{121}$ there are boundaries to that process. This can at least be said for Germany, which has a well-functioning constitutional reviewing process. On the other hand the court also made clear that certain restrictions to the inviolability of the home under art 13 I GG are legal. This way the court attempts to find a balance between the interests of the state in investigating crimes and the personal rights of liberty.

In comparison to the German legislation and assessed according to the standards developed by the German constitutional court, the GCSB Act is lacking some important regulations to protect the privacy of the affected persons. Some of these deficiencies were already present before the GCSB Amendment Bill was passed. However, the amendments made increase these deficiencies. The comparison shows that having a codified constitution means having a better protection of personal rights. The role of the constitutional court in reviewing legislation becomes particularly pivotal in times where governments act hastily in order to to address a threat like terrorism.

${ }^{120}$ Waldron, above $\mathrm{n} 12$, at 3.

121 Waldron, above n 12 , at 3. 


\section{Bibliography}

\section{Cases}

BVerfG (2004) 1 BvR 2378/98, 1 BvR 1084/99.

Verfassungsmäßigkeit handwerksrechtlicher Besichtigungsrechte (1971) (32) BVerfGE 54,75 .

Hosking v Runting [2005] 1 NZLR 1.

$R v$ Jefferies [1994] 1 NZLR 290.

\section{Legislation}

"Gesetz zur Verbesserung der Bekämpfung der Organisierten Kriminalität" vom 4 März 1998 I(25) Bgbl 845.

Gesetz zur Änderung des Grundgesetzes (Artikel 13) vom 26 März 1998.

Gesetz zur Ergänzung des Ersten Gesetzes zur Reform des Strafrechts 1974.

Gesetz zur Änderung des Strafgesetzbuchs, der Strafprozessordnung, des Gerichtsverfassungsgesetzes, der Bunderechtsanwaltsordnung und des Strafvollzugsgesetzes 1976.

Gesetz zur Änderung der Strafprozessordnung 1978.

Gesetz zur Bekämpfung des internationalen Terrorismus (Terrorismusbekämpfungsgesetz) 2002.

Government Communications Security Bureau Act 2003.

Government Communications Security Bureau and Related Legislation Amendment Act 2013.

Bill of Rights Act 1990.

Privacy Act 1993. 


\section{Books and Chapters in Books}

Kirstie Ball and Frank Webster The Intensification of Surveillance. Crime, Terrorism and Warfare in the Information Age (Pluto Press, London, 2003).

James Beckmann Comparative Legal Approaches to Homeland Security and AntiTerrorism (Ashgate, Aldershot, 2007).

Didier Bigo and Anastassia Tsoukala (eds) Terror, Insecurity and Liberty. Illiberal practices of liberal regimes after 9/11 (Routledge, New York, 2008).

Donna-Maree Cross "Surveillance" in Stephen Penk and Rosemary Tobin (eds) Privacy Law in New Zealand (Thomson Reuters, Wellington, 2010) 133.

Laura K Donohue The Cost of Counterterrorism. Power, Politics and Liberty (Cambridge University Press, Cambridge, 2008).

David Dyzenhaus (ed) Civil Rights and Security (Ashgate, Surrey, 2009).

Daniel Farber (ed) Security v. Liberty (Russel Sage Foundation, New York, 2008).

Klaus Günther "World Citizens between Freedom and Security" in David Dyzenhaus (ed) Civil Rights and Security (Ashgate, Surrey, 2009) 433.

Felix Herzog and Dieter Mühlhausen (eds) Geldwäschebekämpfung und Gewinnabschöpfung. Handbuch der straf- und wirtschaftsrechtlichen Regelungen (C H Beck, Munich, 2006).

Jacqueline Klosek The War On Privacy (Praeger, Westport, 2007).

Ian Loader "The Cultural Lives of Security and Rights" in David Dyzenhaus (ed) Civil Rights and Security (Ashgate, Surrey, 2009) 447.

Theodor Maunz and Günter Düring (founders) Grundgesetz Kommentar (68 ed) (CH Beck, München, 2013). 
Stephen Penk "The Privacy Act 1993" in Stephen Penk and Rosemary Tobin (eds) Privacy Law in New Zealand (Thomson Reuters, Wellington, 2010) 49.

Stephen Penk and Rosemary Tobin (eds) Privacy Law in New Zealand (Thomson Reuters, Wellington, 2010).

Eric A Posner and Adrian Vermeule "Emergencies, Tradeoffs, and Deference" in David Dyzenhaus (ed) Civil Rights and Security (Ashgate, Surrey, 2009) 23.

Paul Rishworth and others The New Zealand Bill of Rights (Oxford University Press, Auckland, 2004).

Kent Roach "Must We Trade Rights for Security? The Choice Between Smart, Harsh, or Proportionate Security Strategies in Canada and Britain" in David Dyzenhaus (ed) Civil Rights and Security (Ashgate, Surrey, 2009) 259.

Rosemary Tobin "The Common Law Tort of Invasion of Privacy in New Zealand" in Stephen Penk and Rosemary Tobin (eds) Privacy Law in New Zealand (Thomson Reuters, Wellington, 2010) 79.

Jeremy Waldron "Security and Liberty: The Image of Balance" in David Dyzenhaus (ed) Civil Rights and Security (Ashgate, Surrey, 2009) 3.

Clive Walker "Keeping Control of Terrorists without Losing Control of Constitutionalism" in David Dyzenhaus (ed) Civil Rights and Security (Ashgate, Surrey, 2009) 331 .

Lucia Zedner "Securing Liberty in the Face of Terror: Reflections from Criminal Justice" in David Dyzenhaus (ed) Civil Rights and Security (Ashgate, Surrey, 2009) 231.

\section{Journal Articles}

Ronald D Crelinstein "The Discourse and Practice of Counter-Terrorism in Liberal Democracies" (1998) 44(1) Australian Journal of Politics and History 398.

Erhard Denninger "Freiheit durch Sicherheit? Anmerkungen zum Terrorismusbekämpfungsgesetz" (2002) (10-11) APuZ 22. 
Joachim Dittrich "Der "Große Lauschangriff" - diesseits und jenseits der Verfassung" (1998) NStZ 336.

Thomas I Emerson "Symposium: National Security and Civil Liberties" (1983-4) 69 Cornell L Rev 685.

Conor Gearty "11 September 2011, Counter-terrorism, and the Human Rights Act" (2005) 32(1) Journal of Law and Society 18.

Emanuel Gross "The Struggle of a Democracy Against Terrorism - Protection of Human Rights: The Right to Privacy Versus the National Interest - the Proper Balance" (2004) 37 Cornell Int'l L J 27.

Christoph Gusy "Lauschangriff und Grundgesetz” (2004) JuS 457.

Martin Kutscha "Verfassungsrechtlicher Schutz des Kernbereichs privater Lebensgestaltung - nichts neues aus Karlsruhe?" (2005) NJW 20.

Cynthia Laberge "To What Extent Should National Security Interests Override Privacy in a post 9/11 World?" (2008) 3 Victoria University of Wellington Law Review Working Paper Series.

Klaus Leipold "Der 'große Lauschangriff”" (2005) NJW-Spezial 135.

Oliver Lepsius "Freiheit, Sicherheit und Terror: Die Rechtslage in Deutschland (2004) 32(1) Leviathan 64.

Michael Levi and David S Wall "Technologies, Security, and Privacy in the Post-9/11 European Information Society" (2004) 31(2) Journal of Law and Society 194.

Jürgen Meyer und Wolfgang Hetzer "Neue Gesetze gegen die Organisierte KriminalitätGeldwäschebekämpfung, Gewinnabschöpfung und Einsatz technischer Mittel zur akustischen Überwachung von Wohnungen für Beweiszwecke im Bereich der Strafverfolgung" (1998) NJW 1017. 
Jasper Finke "Über den Sinn und Unsinn eines "Supergrundrechts auf Sicherheit" - oder: wie verfassungstreu ist Innenminister Friedrich? Published on http://www.juwiss.de/finke-uber-den-sinn-und-unsinn-eines-supergrundrechts-aufsicherheit/.

Benjamin Rusteberg "Grundrechte als Supergrundrechte" published on http://www.juwiss.de/2013-79/.

Samuel D Warren and Louis D Brandeis "The Right to Privacy" (1890) 4 Harv L Rev 193.

Verena Zöller "Liberty Dies by Inches: German Counter-Terrorism Measures and Human Rights" (2004) 4 German L J 469.

"Verfassungswidrigkeit des großen Lauschangriffs. Entscheidungsbesprechung zum Urteil” (2004) NJW-Spezial 41.

Other

Matthias Bäcker, Volkmar Giesler, Monika Harms, Burkhard Hirsch, Stefan Kaller and Heinrich Amadeus Wolff Bericht der Regierungskommission zur Überprüfung der Sicherheitsgesetzgebung in Deutschland (Bundesministerium des Innern und Bundesministerium der Justiz, 2013).

Erik van de Linde, Kevin OíBrien, Gustav Lindstrom, Stephan de Spiegeleire, Mikko Vayrynen and Han de Vries Quick scan of post 9/11 national counter-terrorism policymaking and implementation in selected European countries. Research project for the Netherlands Ministry of Justice (RAND Europe, Leiden, 2002).

New Zealand Law Society Submission on the Government Communications Security Bureau and Related Legislation Amendment Bill (14.6.2013).

\section{Theses}

Stephanie Sue-Ling NG "Leave Me Alone! Should the Right of Privacy Be Included in the New Zealand Bill of Rights Act 1990?" (LLB (Hons) Research Paper, Victoria University of Wellington, 2004). 